\title{
COMMENT
}

\section{LONG-TERM BIAS, INCENTIVES, AND AGENCY COSTS}

\author{
Kobi Kastiel*
}

The problem of managerial short-termism has long preoccupied policymakers, researchers, and practitioners. These groups have given much less attention, however, to the converse problem of managerial long-termism. Michal Barzuza and Eric Talley fill this gap in their pioneering article, Long-Term Bias. Relying on the behavioral finance and psychology literatures, the authors provide a novel and thought-provoking analysis of managerial long-term bias, which may be just as detrimental as the more widely condemned short-term bias.

This invited Comment to Barzuza and Talley's article advances three claims. First, it argues that proper incentivescreated by executive compensation, heightened risk of early termination, market responses and shareholder pressuresare likely to turn most managers more realistic and thus to mitigate their long-term biases.

Second, it explains how, in reality, it could be almost impossible to distinguish between long-term bias and traditional agency theories of empire building and pet projects. Ultimately, both long-termist and self-interested managers systematically harm shareholders; both choose to ignore shareholder interests and waste free cash flow on inferior

* Associate Professor, Tel Aviv University Faculty of Law; Research Fellow, Program on Corporate Governance, Harvard Law School. I have benefitted from helpful discussions with Michal Barzuza, Lucian Bebchuk, Assaf Hamdani, Sharon Hannes, and Ehud Kamar, as well as from the comments and questions of the participants at the 2019 TAU/NYU Annual Conference and the IIAS workshop Behavioral Ethics Meets Corporate Governance. I also gratefully acknowledge the excellent research assistance of Gal Rosenfeld. 
business investments. This also explains why the cure to both long-term bias and agency costs is similar: reducing the relative insulation of the board from shareholders' disciplinary power.

Finally, this Comment expresses strong support for most of Barzuza and Talley's normative conclusions, with one important exception: their acceptance of the use of dual-class stock. With a perpetual lock on control and a limited equity stake, corporate leaders will be immune to any "institutional brake" on all forms of long-termist overinvestment. If anything, the analysis of Barzuza and Talley provides an additional strong justification to oppose the use of perpetual dual-class stock.

I. Introduction 835

II. Biases Versus Incentives

A. The Importance of Incentives. 841

B. Mitigating Factors......................................... 845

1. Executive Compensation.............................845

2. Market Signals ............................................8 849

3. Risk of Removal......................................... 851

4. Activist Investors ...................................... 854

III. Long-Term Bias as a Private Benefit?.......................857

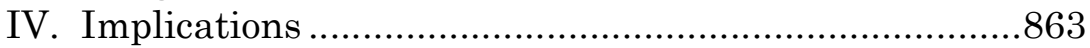

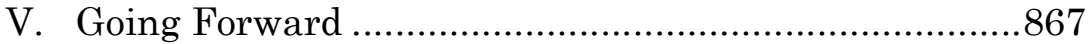

\section{INTRODUCTION}

The problem of managerial short-termism has long preoccupied policymakers, financial economists, governance scholars, and practitioners. 1 The rise of hedge fund activism has reinforced concerns regarding managers' purported tendency to favor the short term at the expense of the long

1 For a review of these different views and the asserted gravity of the debate, see Lucian A. Bebchuk, The Myth that Insulating Boards Serves Long-Term Value, 113 CoLUM. L. REV. 1637, 1646-58 (2013). 
term. ${ }^{2}$ These concerns have led to a heated, ongoing public debate on the very existence of such short-term bias, 3 its financial consequences, ${ }^{4}$ and the need to enact legal reforms to mitigate it. 5

Researchers have given much less attention, however, to the converse problem of managerial long-termism. Barzuza and Talley fill this gap in their thought-provoking and well-

2 See, e.g., John C. Coffee, Jr. \& Darius Palia, The Wolf at the Door: The Impact of Hedge Fund Activism on Corporate Governance, 41 J. CoRP. L. 545, 573 (2016); Leo E. Strine, Jr., Who Bleeds When the Wolves Bite?: A Flesh-and-Blood Perspective on Hedge Fund Activism and Our Strange Corporate Governance System, 126 YALE L.J. 1870, 1884-86, 1892 (2017).

3 See, e.g., Mark J. Roe, Stock Market Short-Termism's Impact, 167 U. PA. L. REV. 71, 113-16 (2018) (arguing that short-termism is relatively unimportant); Charles Nathan \& Kal Goldberg, The Short-Termism Thesis: Dogma Vs. Reality, HARV. L. ScH. F. ON CORP. Governance (Mar. 18, 2019), https://corpgov.law.harvard.edu/2019/03/18/the-short-termism-thesisdogma-vs-reality/ [https://perma.cc/JC5K-LPDK] (challenging "[t]he belief that short-termism . . . is seriously . . damaging our economy").

4 For studies documenting the positive long-term effects of hedge funds, see, e.g., generally Alon Brav, Wei Jiang, Frank Partnoy \& Randall Thomas, Hedge Fund Activism, Corporate Governance, and Firm Performance, $63 \mathrm{~J}$. Fin. 1729 (2008); Lucian A. Bebchuk, Alon Brav \& Wei Jiang, The LongTerm Effects of Hedge Fund Activism, 115 CoLum. L. REV. 1085 (2015). But see generally K.J. Martijn Cremers, Erasmo Giambona, Simone M. Sepe \& Ye Wang, Hedge Fund Activism and Long-Term Firm Value (December 13, 2018) (unpublished manuscript),

https://papers.ssrn.com/sol3/papers.cfm?abstract_id=2693231 (on file with the Columbia Business Law Review) (finding that activist hedge funds pick stocks well but do not cause long-term abnormal stock returns).

5 See, e.g., The Aspen Inst., Overcoming Short-Termism: A CAll For A More Responsible Approach to Investment and Business Management 2-3, 5-6 (2009),

https://assets.aspeninstitute.org/content/uploads/files/content/docs/pubs/ov ercome_short_state0909_0.pdf [https://perma.cc/6WLM-VTWF] (calling for a collective response and approach towards short-termism). But cf. also Martin Lipton, Corporate Governance: The New Paradigm, HARV. L. ScH. F. ON CORP. Governance (Jan. 11, 2017),

https:/corpgov.law.harvard.edu/2017/01/11/corporate-governance-the-newparadigm/ [https://perma.cc/MR5K-3Z82] (encouraging reforms that start with voluntary corporate and investor action). For a review of, and opposition to, such proposed reforms, see, e.g., Bebchuk, supra note 1, at 1640-42. 
written article Long-Term Bias. ${ }^{6}$ Relying on the behavioral finance and psychology literatures, the authors provide a novel analysis of managerial long-term bias. They show that executives could suffer from a long-term bias as well as the commonly-recognized short-term bias, and that focusing on the long term may be just as detrimental as focusing on the short term. ${ }^{7}$ Thus, the intense debate about short-termism is incomplete without recognizing both the converse longtermism bias, and the interactions between the two biases. 8 Barzuza and Talley supplement their analysis by examining three high-profile case studies that demonstrate the negative implications of managerial overconfidence and illustrate how hedge fund activism could provide "a symbiotic counterballast" against it. 9

Barzuza and Talley's analysis has important policy implications for reform proposals. In particular, their analysis provides an additional important justification for reducing managerial insulation.

This Comment, which is an invited response to Barzuza and Talley's article, advances three claims. First, while managers (like other human beings) can be subject to systemic long-term bias, Part II argues that the presence of proper incentives, such as monetary compensation, a potential decline in share price and the threat of removal from office, is likely to mitigate this bias and elicit more sensitive judgments. Managers who do not respond to these incentives, as Barzuza and Talley demonstrate, could also become attractive targets for activist hedge funds.

Consider the example of executive compensation. The traditional economic view posits that risk-averse CEOs should exercise their options or unload their shares when they can to

6 See generally Michal Barzuza \& Eric Talley, Long-Term Bias, 2020 Colum. Bus. L. REV. 104.

7 See id. at 189.

8 Id. at 174 ("[T] he interaction of long- and short-term biases probably does not always result in perfectly optimal outcomes, but by plausibly interacting in this way, short-term bias and long-term bias will tend to mitigate one another's greatest shortcomings.").

9 See id. at 105, 113. 
reduce exposure to firm-specific risk.10 Conversely, if overconfidence and overoptimism motivate most executives, it should be anticipated that most of them will increase their equity holdings or hold on to an option until late in the option's life, and that such behavior will cause them to overinvest in the long-term even without earning significant abnormal returns. 11 The empirical evidence, however, shows that only a minority of CEOs hold their options beyond the required holding period. 12 Evidence also shows that executives often dispose of equity-based pay upon vesting, 13 and that most CEO stock ownership policies are ineffectual in practice, as CEOs tend to sell their vested stock rights when they can.14 This suggests that CEOs, on average, respond to financial incentives and behave rationally.

Another example involves stock market reactions to investment announcements. It can be assumed that managers with long-term biases are prone to ignore such external signals, whereas rational managers will respond to market signals in order to avoid the risk of early termination. Here again, empirical evidence shows that when the market expresses clear dissatisfaction with a contemplated transaction, managers behave rationally. 15

10 For a review of this literature, see Ulrike Malmendier \& Geoffrey Tate, CEO Overconfidence and Corporate Investment, 60 J. Fin. 2661, 2663 (2005) [hereinafter Malmendier \& Tate, Corporate Investment].

11 See id. at 2663, 2671.

12 See id. at 2669 tbl.1, 2673; Ulrike Malmendier \& Geoffrey Tate, Who Makes Acquisitions? CEO Overconfidence and the Market's Reaction, 89 J. Fin. ECON. 20, 25 tbl.1 (2008) [hereinafter Malmendier \& Tate, Market's Reaction].

13 See Alex Edmans, Vivian W. Fang \& Katharina A. Lewellen, Equity Vesting and Investment, 30 REV. FIN. STUD. 2229, 2230 (2017).

14 Nitzan Shilon, CEO Stock Ownership Policies-Rhetoric and Reality, 90 IND. L.J. 353, 369-71, 394-95 (2015).

15 See James B. Kau, James S. Linck \& Paul H. Rubin, Do Managers Listen to the Market?, 14 J. CORP. FIN. 347, 348, 361 (2008); Yuanzhi Luo, Do Insiders Learn from Outsiders? Evidence from Mergers and Acquisitions, 60 J. Fin. 1951, 1951-54 (2005); Baixiao Liu \& John J. McConnell, The Role of the Media in Corporate Governance: Do the Media Influence Managers' Capital Allocation Decisions?, 110 J. FIn. Econ. 1, 2 (2013). 
Similarly, if a CEO with a long-term bias consistently pursues long-term strategies that harm shareholders, such bias should increase their likelihood of being replaced. The recent decline in average CEO tenure, 16 combined with the increase in investor engagement, suggests that this risk of early termination is real.17 Under these circumstances, managers have limited incentives to invest in long-term projects with uncertain benefits which would accrue only well after the anticipated lengths of their terms. 18

It should be clarified that the analysis I present in Part II does not deny that some managers will suffer from long-term bias. Despite the mitigating impact of incentives, some managers could still exhibit a bias toward inferior long-term projects and bear personal losses. Nonetheless, when motivating incentives such as those discussed in Part II are present, managers are less likely on average to exhibit a persistent long-term bias.

Second, Part III questions the distinction between longterm bias and traditional agency theories of empire building. The behavioral economics literature tries to distinguish longterm bias because the agency theories involve a decisionmaker's intentional behavior.19 But from the

16 Dan Marcec, CEO Tenure Rates, HARV. L. Sch. F. ON CORP. Governance (Feb. 12, 2018),

https://corpgov.law.harvard.edu/2018/02/12/ceo-tenure-rates/ [https://perma.cc/2AF5-FM94].

17 See Reena Aggarwal, Sandeep Dahiya \& Nagpurnanand R. Prabhala, The Power of Shareholder Votes: Evidence from Uncontested Director Elections, 133 J. Fin. Econ. 134, 134-36 (2019); Michal Barzuza, Quinn Curtis \& David H. Webber, Shareholder Value(s): Index Fund ESG Activism and the New Millennial Corporate Governance, 93 S. CAL. L. REV. (forthcoming 2020) (manuscript at 124-25) (describing how index funds exert pressure on boards by backing their advocacy with votes).

18 This analysis is limited to companies without a controlling shareholder. When companies have controlling shareholders, a shareholder vote is meaningless, and the likelihood of activist intervention is substantially lower than in the case of widely-held companies. See Kobi Kastiel, Against All Odds: Hedge Fund Activism in Controlled Companies, 2016 Colum. Bus. L. REV. 60, 70-74.

19 See Barzuza \& Talley, supra note 6, at 177 (implicitly suggesting this distinction). 
perspective of public shareholders, should the lack of intention make a difference? Ultimately, both types of behaviors systematically harm shareholders, and in both cases corporate leaders choose to ignore shareholder interests and waste free cash flow on inferior business investments that provide them with private benefits of control.

Moreover, distinguishing between overconfidence and traditional agency costs ex post could prove complicated if not impossible. Consider the three case studies presented by Barzuza and Talley. While they can be viewed as examples of managerial long-term bias, an equally plausible interpretation would view them as examples of pet projects that provided the CEOs of these companies with psychic private benefits. This also explains why the cure to both longterm bias and agency costs is similar: reducing the relative insulation of the board from shareholders' disciplinary power so that shareholders can hold managers accountable when they underperform.

Finally, Part IV discusses the policy implications of Barzuza and Talley's analysis. Most of their recommendations for mitigating long-term bias-by reducing managerial insulation, increasing accountability by upholding quarterly reporting, and enabling hedge funds to engage with targets20_have merit. Unlike Stephen Bainbridge, who rejects Barzuza and Talley's recommendations,21 I strongly support most of their normative conclusions, with one important exception: their acceptance of the use of dual-class stock. 22

Founders are especially prone to overconfidence and overoptimism, which could manifest in long-term biases. Having a perpetual lock on control and a limited equity stake, these founders are immune to any "institutional brake" on any form of long-termist overinvestment.23 I posit that, if anything, Barzuza and Talley's analysis, which calls for increasing

20 See id. at 181-83.

21 Stephen Bainbridge, Comment, Long-Term Bias and Director Primacy, 2020 Colum. Bus. L. REV. 801, 818-24.

22 See Barzuza \& Talley, supra note 6, at 183-85.

23 See id. 
managerial accountability, provides an additional strong justification to oppose the use of dual-class stock: to put an end to founders' perpetual insulation from shareholder intervention.

\section{BIASES VERSUS INCENTIVES}

\section{A. The Importance of Incentives}

Barzuza and Talley draw upon the large body of literature in psychology and behavioral economics that documents a widespread human tendency to be overconfident in their abilities and overly-optimistic, with such biases causing irrational behavior. 24

Corporate managers are not different. If anything, according to Barzuza and Talley, these executives appear to be particularly prone to overconfidence and optimism. As the authors explain, managerial decisionmakers tend to suffer from the "illusion of control." 25 Managers also "tend to discount feedback and relevant data; and ... tend to receive such feedback more sporadically for long-term endeavors." 26 Consequently, they conclude that "managers' long-term

24 As Shelley E. Taylor \& Jonathon D. Brown summarize:

[A] great deal of research in social, personality, clinical, and developmental psychology documents that normal individuals possess unrealistically positive views of themselves, an exaggerated belief in their ability to control their environment, and a view of the future that maintains that their future will be far better than the average person's.

Illusion and Well-Being: A Social Psychological Perspective on Mental Health, 103 PsYch. BulL. 193, 197 (1988). Evidence that such biases extend to management students, entrepreneurs, and corporate presidents appears, for example, in Colin Camerer \& Dan Lovallo, Overconfidence and Excess Entry: An Experimental Approach, 89 AM. ECON. REv. 306, 310, 311 \& n.6, 312-16 (1999).

25 A CEO who hand-picks an investment project is likely to believe he can control its outcome and underestimate the likelihood of failure. See Barzuza \& Talley, supra note 6 , at $143-47$.

26 Id. at 112. 
projects are particularly prone to persistent overestimation." 27

Long-term biases come with costs. Barzuza and Talley define long-term bias as a "preference for a long-term investment over a superior short-term investment/return" and short-term bias as a "preference for a short-term investment/gain over a superior long-term investment/return."28 This suggests a crucial difference between these two biases. Short-term bias presents a clear trade-off: investors enjoy liquidity and early realization of their investments in exchange for inferior returns. Long-term bias, however, is a lose-lose proposition. Investors suffer from a delayed realization of their investments and inferior returns. Why would managers make such value-decreasing decisions that investors have no reason to favor?

There are a few possible explanations. The first is that managers, at the expense of other investors, derive some private benefits from this strategy. I address this suggestion in the next part. ${ }^{29}$ The second explanation, offered by Barzuza and Talley, is that managers "genuinely (but mistakenly) believe in the quality of their long-term investment[]" decisions. 30

These genuine mistakes could be costly not only for investors but also for corporate managers. Managers who have a systematic tendency to choose long-term endeavors with inferior returns could suffer significant economic losses in the form of low compensation, high risk of early termination, a decline in their company's share price, and reputational damages. 31 They also could be subject to interventions by activist hedge funds, as shown by Barzuza and Talley. 32

27 Id.

28 Id. at 135 tbl. 1.

29 See infra Part III.

30 Barzuza \& Talley, supra note 6, at 177.

31 For a discussion of each of these mitigating factors and their impact, see infra Section II.B.

32 See Barzuza \& Talley, supra 6, at 156-72 (describing examples of such interventions). 
As financial economists and corporate governance scholars have long taught, incentives matter. ${ }^{33}$ Therefore, at least in theory, we would assume that when financial rewards are high, the average CEO has strong incentives to be attentive to negative signals and avoid inferior long-term investments: they do not want to lose their position or suffer financial losses.

The interesting question, therefore, is not whether managers may be subject to systemic biases that have a negative impact on their long-term decisionmaking (they probably are) but rather what happens to their confidence and accuracy when financial incentives and behavioral biases interact. How could proper incentives influence confidence? Would they elicit less bias and more sensitive and accurate judgments? Would the magnitude or valence of the incentives - that is, the prospect of losses or gains-have an influence? And what fraction of managers will remain indifferent or even increase their overconfidence despite large countervailing monetary incentives?

Empirical studies in behavioral psychology have investigated methodically the interactions between incentives and confidence. Some of these studies have found that incentives increase the precision of a person's estimations. For example, a study by Kritzan and Windschitl discusses possible factors mitigating over-optimism. 34 They provide an example of a person who will receive $\$ 1,000$ if Company A receives a contract. That person, they argue, will be more sensitive to negative information about Company A than they would be if no money were at stake. 35

33 For discussions of the effect of incentives on managerial decisionmaking, see, e.g., generally Michael C. Jensen \& William H. Meckling, Theory of the Firm: Managerial Behavior, Agency Costs and Ownership Structure, 3 J. FIn. ECON. 305 (1976); LUCIAN BEBCHUK \& JESSE Fried, Pay Without Performance: The Unfulfilled Promise of Executive Compensation (2004) (discussing the effect of incentives in the context of executive pay).

34 Zlatan Krizan \& Paul D. Windschitl, The Influence of Outcome Desirability on Optimism, 133 Psych. Bull. 95, 106-12 (2007).

35 See id. at 108. 
Another study examined the way incentives can mitigate students' overconfidence when they try to predict their grades. ${ }^{36}$ Believing that incentives might motivate students to be more realistic in their self-assessments, a researcherinstructor offered students extra credit if they accurately forecasted the number of multiple-choice questions they would answer correctly on an upcoming exam. 37 The study found that "[g]enerally, the incentive scheme result[ed] in fewer extreme forecast errors for most groups of students." 38 Supporting these results, a third study found that real monetary incentives (rather than extra credit) also "mitigate overestimation of potential achievements and eliminate overestimation of actual achievements." 39

Finally, Camerer and Hogarth reviewed 74 experiments using no, low, or high performance-based financial incentives and found that "the presence and amount of financial incentive does seem to affect average performance in many tasks," but not always, and that "higher levels of incentives have the largest effects in judgment and decision tasks." 40

36 See generally Dennis Caplan, Kristian G. Mortenson \& Marisa Lester, Can Incentives Mitigate Student Overconfidence at Grade Forecasts?, 27 AcCT. EDUC. 27 (2018).

$37 \quad I d$. at 33 .

38 Id. at 28.

39 Noemí Herranz-Zarzoso \& Gerardo Sabater-Grande, Monetary Incentives and Overconfidence in Academic Performance: An Experimental Study 25-26 (Econ. Dep't, Universitat Jaume I, Working Paper 2020/14, 2020),

http://www.doctreballeco.uji.es/wpficheros/Herranz_and_Sabater_14_2020. pdf [https://perma.cc/YZU2-LFZY] (quotation in abstract); see also Maël Lebreton et al., Two Sides of the Same Coin: Monetary Incentives Concurrently Improve and Bias Confidence Judgments, SCI. AdVANCES, May 30,2018 , at 8 (finding that "high (or low) confidence is more closely associated with correct (or incorrect) decisions when confidence reports are incentivized" and that "[t]he prospect of gains increases confidence, while the prospect of losses decreases confidence").

40 Colin F. Camerer \& Robin M. Hogarth, The Effects of Financial Incentives in Experiments: A Review and Capital-Labor-Production Framework, 19 J. Risk \& UNCERTAINTY 7, 8, 19-21, 34-35 (1999) ("Incentives improve performance in easy tasks that are effort-responsive, like judgment, prediction, [and] problem-solving . . . Incentives sometimes 
Taken together, these studies show that people tend to be less optimistic and more realistic when financial or other rewards are at stake.

\section{B. Mitigating Factors}

This section identifies and explores several factors that could mitigate managerial long-term bias. Such factors include executive compensation, market signals, risk of removal, and activist shareholders. 41 With these mitigating mechanisms in place, we should expect managers of companies in competitive markets to make more sensitive and accurate judgments. Otherwise, they will bear substantial costs.

Before proceeding, it should be clarified that the analysis herein does not deny that some managers will suffer from long-term bias. Despite the mitigating impact of financial incentives, some managers could still exhibit a bias toward inferior long-term projects and suffer personal losses. 42 Nonetheless, when motivating incentives such as those discussed below are present, managers are less likely on average to continue to exhibit such irrational behavior.

\section{Executive Compensation}

In recent years, there has been a push toward aligning executive compensation with a firm's long-term value and performance. 43 Investors, regulators, and corporate governance scholars long have emphasized the need to ensure

hurt when problems are too difficult or when simple intuition or habit provides an optimal answer and thinking harder makes things worse. In games, auctions, and risky choices the most typical result is that incentives do not affect mean performance, but incentives often reduce variance in responses. In situations where there is no clear standard of performance, incentives often cause subjects to move away from favorable "selfpresentation' behavior toward more realistic choices.").

41 This section discusses the last factor only briefly, as Barzuza and Talley discuss it at length. See Barzuza \& Talley, supra note 6, at 173-81.

42 See id. at 177, 187 n.348 (citing Malmendier \& Tate, Corporate Investment, supra note 10, at 2697).

43 See Shilon, supra note 14, at 361-63. 
that the compensation of public company executives is tied to long-term results in order to prevent executives from attaching excessive weight to short-term prices and to avoid creating incentives for excessive risk-taking. 44 The mechanism of executive compensation-when it operates well-serves an important disciplinary function, as it provides managers with strong incentives not to make investments with inferior long-term returns. Making these investments would result in significant losses for managers in the form of a decline in the value of their equity-based compensation. 45

Scholars have long emphasized the need to tie executive pay to the long term because rational risk-averse CEOs have incentives to reduce their exposure to company-specific risk by unloading their equity position or exercising their stock options early if those options are sufficiently deep in the money (that is, they have a market price above the strike price of the stock). 46 Doing so would reduce the risk of suffering significant losses in case of a failure of a risky venture.

Barzuza and Talley argue that executive compensation incentives are unlikely to play a meaningful disciplinary function in the case of overconfident managers. This is because "overconfident managers-who genuinely (but mistakenly) believe in the quality of their long-term investments-are encouraged to invest even more when their compensation is tied to firm value." 47 Thus, tying compensation to long-term results would just aggravate overconfident managers' biases, as it would provide them with an additional incentive to invest even more in long-term projects. For the same reason, it might be expected that a CEO

44 See, e.g., Lucian A. Bebchuk \& Jesse M. Fried, Paying for Long-Term Performance, 158 U. PA. L. REV. 1915, 1916-19 (2010).

45 See Shilon, supra note 14, at 361-62; cf. also Andrew Ludwig, CEO Pay Trends Around the Globe, Harv. L. ScH. F. on CoRP. Governance (Feb. 3, 2019), https://corpgov.law.harvard.edu/2019/02/03/ceo-pay-trendsaround-the-globe/ [https://perma.cc/4TPG-7XBH] (providing data on the use of equity based compensation in the United States and around the world).

46 See Malmendier \& Tate, Corporate Investment, supra note 10, at 2671.

47 Barzuza \& Talley, supra note 6 , at 177. 
who suffers from long-term bias will hold on to an option until late in the option's life even if the option is already deep in the money. Holding on in this way is evidence of optimistic beliefs about the company's prospects. 48

The question of whether executive compensation packages and their linkage to long-term benchmarks mitigate or aggravate long-term bias is essentially an empirical one. If long-term bias motivates most executives, it should be anticipated that most of them will hold on to an option until late in the option's life, and that such equity holding will cause them to over-invest in the long-term. 49

The evidence, however, does not support this expectation, as the data show that most managers react to executive compensation incentives rationally in order to reduce their potential losses (or increase their gains). 50 For example, a well-known study by Malmendier and Tate shows that only about thirteen percent of the CEOs in their sample held their options to the end of the option period and consequentially bear financial losses. 51

This finding is consistent with those of related studies. Edmans, Fang, and Lewellen, for example, found that executives often dispose of equity-based pay upon vesting. 52 Similarly, Nitzan Shilon has shown that CEO stock ownership

48 See Malmendier \& Tate, supra note 10, Corporate Investment, at 2671.

49 See id.

50 In theory, one could argue that even long-termist executives choose to sell their options when they can because they prefer greater liquidity and flexibility. Most executives, however, also receive cash compensation and thus are unlikely to have liquidity needs. See supra note 45 . Therefore, if these executives (who also have access to inside information) are truly optimistic about the company's prospects and are not motivated by selfinterest, they would keep holding their shares instead of selling as soon as they can-a practice that has been subject to significant criticism. See, e.g., Bebchuk \& Fried, supra note 44, at 1923.

51 See Malmendier \& Tate, Corporate Investment, supra note 10, at 2673.

52 See Edmans et al., supra note 13, at 2229, 2230 ("[V] esting equity . . . is highly correlated with actual short-term equity sales: a one-standarddeviation increase in vesting equity is associated with a rise in samequarter equity sales by $\$ 140,000,16 \%$ of the average level.”). 
policies, widely adopted by leading firms for the purpose of aligning managers' interests with those of their long-term shareholders, 53 are ineffectual in practice because CEOs tend to sell their vested stock as soon as they can. 54

This empirical evidence indicates that CEOs, on average, respond to financial incentives and behave rationally. They prefer to exercise the options and unwind their equity holdings when they can in order to reduce their firm-specific risk.

Additional studies have shown that when CEOs can unwind their equity holdings quickly, they are more likely to act myopically. For example, studies have found that executives cut investments and report higher short-term earnings when they can exercise their options earlier, 55 that executive compensation contracts with shorter-duration correlate "with greater managerial incentive to manipulate short-term performance," 56 and that an increase in equity vesting correlates with a decline in R\&D growth and with positive analyst forecast revisions. 57 Other work has shown that firms whose executives are about to retire are more likely to be acquired. 58

53 Shilon, supra note 14, at 361-63 (discussing the use of compensation to minimize agency costs by tying together executives' and shareholders' interests).

54 See id. at 394-95 (discussing this issue with an example).

55 See Tomislav Ladika \& Zacharias Sautner, Managerial ShortTermism and Investment: Evidence from Accelerated Option Vesting, 24 REV. Fin. 305, 327 (2020).

56 See Radhakrishnan Gopalan et al., Duration of Executive Compensation, 69 J. Fin. 2777, 2812 (2014).

57 Edmans et al, supra note 13, at 2230; cf. Alex Edmans, Vivian W. Fang \& Allen H. Huang, The Long-Term Consequences of Short-Term Incentives 15, 21 (Eur. Corp. Governance Inst., Fin. Working Paper No. 527/2017, June 2020),

https://papers.ssrn.com/sol3/papers.cfm?abstract_id=3037354 (on file with the Columbia Business Law Review) (associating vesting with repurchases and mergers and acquisitions as well).

58 Dirk Jenter \& Katharina Lewellen, CEO Preferences and Acquisitions, 70 J. FIn. 2813, 2830 (2015). 


\section{Market Signals}

Barzuza and Talley explain that "[w]hile short-term bias originates primarily from external sources such as capital market investors, long-term bias emerges internally, from managers' assessments about their own long-term projects." 59 This important distinction suggests that "managers are inclined to be highly optimistic in general" 60 because they lack the unbiased perspective of an outsider. It also suggests that investors are not the primary cause of managerial long-term bias, which emerges internally.

Managers constantly receive signals from investors and the stock market.61 It can be assumed that, due to their overoptimism and overconfidence, managers with long-term biases are less attentive to external signals, whereas rational managers respond to market signals in order to avoid the risk of early termination. 62 The question of the extent to which managers can ignore market signals and bear the price associated with inattentiveness to the market is, ultimately, an empirical one.

Existing evidence supports the view that, in general, managers do respond to market signals. For example, a study by Kau, Linck, and Rubin examined whether a negative market response to an announced investment affects the probability of the same investment being executed. They found that "managers are more likely to cancel investments when the market reacts unfavorably to the investment's announcement" and that "[d]eals that the market predicts to

59 Barzuza \& Talley, supra note 6, at 112 (emphasis added).

60 Id.

61 See Jeffrey N. Gordon, The Rise of Independent Directors in the United States, 1950-2005: Of Shareholder Value and Stock Market Prices, 59 STAN. L. REV. 1465, 1541-43 (2007) (describing the reliability and use of stock market signals).

62 See id. at 1531 ("The second strategic element of the 1990s boards' focus on shareholder value was increasingly to evaluate CEO performance with respect to shareholder returns and to terminate more quickly."). For empirical evidence on the increased riskiness of the CEO job, see Steven N. Kaplan, CEO Pay and Corporate Governance in the U.S.: Perceptions, Facts, and Challenges, 25 J. ApPliEd CoRP. Fin., Summer 2013, at 8, 15, 16 \& fig.10. 
have higher returns are more likely to be completed than deals with lower market returns."63 They also demonstrate "that managers are more likely to listen to markets when their pay is more sensitive to performance."64

Another study found similar results, suggesting that executives learn from stock market reactions to merger and acquisition (M\&A) announcements, and, consequently, that those reactions can predict the probability of the completion of an M\&A transaction.65 More specifically, using a large sample of domestic M\&A transactions, the study found that "the combined bidder and target abnormal return around the announcement predicts whether the companies will later consummate the deal."66

Finally, a third study suggests that managers suffer from two types of losses when announcing a value-decreasing acquisition. One type of loss is that of the tangible capital possessed through shares in the company. 67 The second type of loss involves damage to human capital in the form of managers' reputations. ${ }^{68}$ After examining 636 proposed M\&A transactions which triggered a negative stock market reaction, the study found that the "level of media attention and the tone of media coverage play an important role in managers' decisions to abandon value-reducing acquisition attempts."69

Thus, the empirical evidence presented in this Section suggests that when the market clearly disfavors a transaction, managers are reluctant to ignore that signal. When clear financial interests are at stake, managers' behavioral biases are less severe.

\footnotetext{
63 Kau et al., supra note 15, at 348, 361.

64 Id. at 361.

65 See Luo, supra note 15, at 1951-54.

66 Id. at 1978.

67 See Liu \& McConnell, supra note 15, at 2.

68 See id.

69 Id. at 2, 4-5.
} 


\section{Risk of Removal}

If CEOs with long-term biases consistently ignore market signals and pursue strategies that harm shareholders, this will affect their reputations and undermine their likelihoods of retaining their offices. Since many CEOs also chair their boards, shareholders can vote against them in a corporate election.70 Even if the CEO does not sit on the board, shareholders can exercise pressure on the board to remove underperforming CEOs.

An analogy to the political arena is useful. Politicians, like corporate leaders, are prone to over-optimism and overconfidence. ${ }^{71}$ These biases could be even more severe in the case of politicians because many politicians do not face outside actors (like activist investors or hostile bidders) who can terminate politicians' tenures prematurely. ${ }^{72}$ Despite the potential effect of over-optimism and overconfidence, the political science literature shows that politicians invest in short-term public goods even when investing in long-term public goods would be better for society. This phenomenon, known as "political short-termism," 73 is motivated by politicians' desires to be re-elected and voters' tendencies to discount the future and give greater weight to the present. 74

If the analogy with politicians holds, CEOs would have no incentive to act against the will of shareholders. Shareholders could "punish" executives who try to promote inferior long-

70 For empirical evidence on the number of CEOs who also serve as chairmen of the boards, see Matteo Tonello, The Conf. BD., Corporate BoARD PRACTICES IN THE RUSSELl 3000 AND S\&P 500, at 85 fig.1.11 (2019), https://www.russellreynolds.com/en/Insights/thought-

leadership/Documents/TCB-Corporate-Board-Practices-2019.pdf [https://perma.cc/Y4LR-J4CP].

71 See generally Pietro Ortoleva \& Erik Snowberg, Overconfidence in Political Behavior, 105 Am. Econ. REV. 504 (2015).

72 For a discussion of activist investors, see infra Section II.B.4.

73 Iconio Garrì, Political Short-Termism: A Possible Explanation, 145 Pub. CHoICE 197, 198-199, 205 (2010).

74 Michael K. MacKenzie, Institutional Design and Sources of ShortTermism, in Institutions For Future Generations 24, 25-27 (Iñigo González-Ricoy \& Axel Gosseries eds., 2016). 
term projects either directly (by voting against executives serving on the board) or indirectly (by pressing the board to replace the CEO). 75 Moreover, a large percentage of public companies now hold corporate elections on an annual basis. ${ }^{76}$ Thus, underperforming CEOs who serve as directors, as well as the directors who nominated them, now face the threat of negative votes even in uncontested elections. Such risk has been on the rise in recent years due to increased shareholder engagement. 77

The number of directors (including CEOs on the board) who fail to receive significant support from their shareholders has risen, meaning that shareholders have used their votes to express meaningful dissatisfaction with increasing frequency. 78 Data also show that "there [is] a non-trivial number of companies in which management fails to receive significant support" on say-on-pay votes.79 The lack of significant shareholder support in these votes often is a

75 See Marcel Kahan \& Edward Rock, Embattled CEOs, 88 TEX. L. REV. 987, 1040 (2010) ("[T] makes mistakes (or perhaps just has bad luck), both shareholders and directors will voice their criticism sooner and more strongly than in the days of yore."); Gordon, supra note 61, at 1531-34.

76 For example, in 2018, about $90 \%$ of the companies in the S\&P 500 and over $70 \%$ of the companies in the S\&P 1500 hold annual elections. See David F. Larcker \& Brian Tayan, Loosey-Goosey Governance: Four Misunderstood Terms in Corporate Governance 9 exhibit 2 (Rock Ctr. for Corp. Governance, Stanford Univ., Stanford Closer Look Series Paper CGRP79, Oct. 7, 2019),

https://papers.ssrn.com/sol3/papers.cfm?abstract_id=3463958 (on file with the Columbia Business Law Review).

77 See Kahan \& Rock, supra note 75, at 1040.

78 Kobi Kastiel \& Yaron Nili, Competing for Votes, 10 Harv. Bus. L. REV. 287, 319-20 (2020) ("[From 2015 to 2019] the number of directors failing to receive majority support from their shareholders rose from 345 . . to $478 \ldots$ [and] [t] he number of directors failing to receive at least $70 \%$ support rose by over $45 \%$. . f from 1185 . . to $1726 . ")$.

$79 I d$. at 314-15. The say-on-pay rule requires that shareholders at public companies vote a non-binding resolution either approving or disapproving the compensation packages of senior executives. See 15 U.S.C. $\S 78 n-1$ (2018); 17 C.F.R. $§ 240.14 a-21$ (2020). 
reflection of overall shareholder dissatisfaction with management. 80

Protest votes are an important vehicle for shareholders to communicate their preferences to the board and senior management. A large body of empirical research suggests that corporate directors pay attention to voting outcomes and in many cases incorporate the results into their future decisions. ${ }^{81}$ For example, a recent study found that protest votes in uncontested director elections have a substantial negative impact on an affected director's career, increasing the likelihood that the director will leave the board and decreasing that director's future opportunities in the director labor market. 82 More importantly, the evidence shows that director elections also play a significant role in the performance sensitivity of CEO turnover 83 and that firms with low voting approval are more likely to experience CEO

80 See Jill Fisch, Darius Palia \& Steven Davidoff Solomon, Is Say on Pay All About Pay? The Impact of Firm Performance, 8 HARV. Bus. L. REV. 101, 129 (2018).

81 Cf., e.g., Barzuza et al., supra note 17 (manuscript at 131-32) (illustrating the influence of index fund votes on management decisions with the example of board diversification pushes).

82 See Aggarwal et al., supra note 17, at 134-36; see also William C. Johnson, Jonathan M. Karpoff \& Michael D. Wittry, The Consequences to Directors of Deploying Poison Pills 1-4, 8-9 (Fisher Coll. of Bus. Working Paper 2019-03-023, Aug. 30, 2019),

https://papers.ssrn.com/sol3/Data_Integrity_Notice.cfm?abid=3460201 (on file with the Columbia Business Law Review) (discussing the effects of adopting unpopular poison pills). Another study shows that when management is attentive to shareholder demands and implements governance-related proposals that receive majority support, there is an "approximately ... one-fifth reduction in [both] the probability of director turnover .... [and] the probability of losing directorships held in other firms.” See Yonca Ertimur, Fabrizio Ferri \& Stephen R. Stubben, Board of Directors' Responsiveness to Shareholders: Evidence from Shareholder Proposals, 16 J. CoRP. Fin. 53, 54 (2010).

83 See Vyacheslav Fos, Kai Li \& Margarita Tsoutsoura, Do Director Elections Matter?, 31 REv. Fin. STUd. 1499, 1501 (2018); Bonnie G. Buchanan et al., Shareholder Proposal Rules and Practice: Evidence from a Comparison of the United States and United Kingdom, 49 AM. Bus. L.J. 739, $786,790,795-96$ (2012) (discussing the roles of shareholder proposals in increasing CEO turnover and separating the CEO and Chairman positions). 
turnover, lower CEO compensation, and increased corporate activity (such as a major asset sale or an acquisition) in the year following an unfavorable vote. 84

Finally, evidence also shows that, at least at large firms, expected CEO tenure has declined by half, from ten years in 1970's to five years in 2017.85 This decline in managers' average tenure suggests that the risk of early termination is real.86 Shorter tenures reduce the likelihood of inferior longterm investments because managers have limited incentives (that decline even further over their tenure) to invest in projects with long-term horizons and uncertain benefits: these benefits would accrue well after the anticipated lengths of their terms. 87

The empirical evidence shows that shareholder voting is no longer inconsequential and that long-lasting tenure is no longer guaranteed. Thus, if managers invest in inferior projects that shareholders disfavor, they could face significant negative consequences.

\section{Activist Investors}

In the past two decades, activist hedge funds have become critical players in the corporate governance arena. 88 These funds often accumulate large but non-controlling stakes in

84 See Paul E. Fischer et al., Investor Perceptions of Board Performance: Evidence from Uncontested Director Elections, 48 J. ACCT. \& ECON. 172, 180, 183-86 (2009).

85 See Marcec, supra note 16 (providing data on CEO Tenure Rates between 2013 and 2017); Kaplan, supra note 62, at 16 fig.10 (providing historical data on CEO turnover).

86 See supra note 62.

87 See Bainbridge, supra note 21, at 810-11.

88 Between 2013 to 2017, 642 directors nominated by activist hedge funds gained board seats across corporations of at least moderate size. See Sullivan \& CROMWELl LLP, REVIEW AND ANALYSIS OF 2017 U.S. SHAREHOLDER ACTIVISM 12 tbl.Board Seats Obtained by Activists (2018), https://www.sullcrom.com/siteFiles/Publications/SC_Publication_Review_a nd_Analysis_of_2017_US_Shareholder_Activism.pdf

[https://perma.cc/EG7Z-EN6H]; see also generally Lucian A. Bebchuk, Alon Brav, Wei Jiang \& Thomas Keusch, Dancing with Activists, 137 J. FIN. ECON. 1 (2020) (providing data on activists' settlements with boards). 
allegedly underperforming target companies in order to effect change in the those companies' strategic, operational, or financial policies.89 They might propose, for example, divesting assets, changing investment or payout levels, altering capital structure, or replacing the CEO, often while threatening to nominate their own representatives to the board if target companies are unresponsive to their demands. 90

Activist hedge funds undoubtedly do not suffer from a longterm bias. 91 Their presence in a company with managers who demonstrate long-term bias can mitigate such bias. ${ }^{92}$ Indeed, Barzuza and Talley devote a significant part of their Article to explaining how activist hedge funds may be "an institutional "chaperone"'93 to and "effective counter ballast"94 against longtermist overinvestment. They also offer fascinating examples from three well-known companies-Yahoo, AOL, and Navistar- "where long-term investment decisions were arguably biased by overconfidence, and their most deleterious effects were ultimately interrupted by hedge fund activism."95

There is no need here to delve into the role that activist hedge funds play in mitigating managerial long-termism; Barzuza and Talley have documented it thoroughly and convincingly. 96 However, one additional insight about activist hedge funds does merit attention: they help to curb managerial long-termism not just by discontinuing valuedecreasing investments ex post but also by providing ex ante incentives to managers to be more attentive to shareholder

89 See Bebchuk et al., supra note 4, at 1090, 1106; Coffee \& Palia, supra note 2 , at 573-74.

90 See Brav et al., supra note 4, at 1730-1731; Coffee \& Palia, supra note 2 , at $582-583$.

91 See Marcel Kahan \& Edward B. Rock, Hedge Funds in Corporate Governance and Corporate Control, 155 U. PA. L. REV. 1021, 1083-84 (2007).

92 See Barzuza \& Talley, supra note 6, at 173-75.

93 Id. at 120

94 Id. at 173.

95 Id. at 155.

96 See id. at $173-75$. 
demands and to perform well.97 If management is concerned about the likelihood of becoming an activist target, even in the absence of actual activist engagement, "management will try ex ante to avoid such a campaign ... by proactively taking steps to increase shareholder value, such as increasing leverage or decreasing capital expenditures."98 Boards with a healthy respect for communication with shareholders will find success.99 At the other extreme, failure to engage with shareholders can be detrimental to management in firms later facing activist challenges. 100

At this point, I have discussed four major factors that could curb managerial long-termism, at least in the majority of the cases: executive compensation, market signals, risk of removal, and hedge fund activism. To be clear, the presence of these mitigating incentives does not ensure that managers will always make decisions that align with shareholder interests. As agency theories show, managers could have incentives to deviate from optimal decisions in order to advance their self-interest at the expense of maximizing shareholder value. 101

In addition, some scholars view the board of directors as another mitigating force and argue that the task of policing managerial time horizon biases should be left to the board.102 Directors can curb managerial long-term bias only to the extent that they can exert significant influence over overconfident managers. But as Yaron Nili and I have shown elsewhere, "independent" board members are often too dependent on the information management chooses to provide or conceal, as well as on the manner in which management

97 See Kastiel \& Nili, supra note 78, at 302.

98 Id.; see also Assaf Hamdani \& Sharon Hannes, The Future of Shareholder Activism, 99 B.U. L. REV. 971, 984-85 (2019).

99 See Hamdani \& Hannes, supra note 99, at 985-92 (discussing the incentives for corporations to communicate with activist shareholders).

100 See id.

101 For a fuller discussion of this point, see infra Part III.

102 See, e.g., Bainbridge, supra note 21, at 833. 
presents it to the board.103 We classify this as the "informational capture" of the board.104 Independent directors also lack time and adequate resources to properly digest and analyze the information they receive, and they often lack knowledge of the specific characteristics of the firm on whose board they sit or even of the firm's industry.105 Moreover, studies have shown that CEOs may exercise strong influence over directors' nominations, which could affect the latter's decisionmaking processes. 106

Together, informational capture and the power dynamic in a company will impact the possibility of directors being able to mitigate long-term bias. Barzuza and Talley have demonstrated convincingly that increasing board insulation from shareholder activism and hedge fund intervention is likely to exacerbate, rather than mitigate, managerial longterm bias and will reduce their accountability to public investors. 107 I discuss this point in Part IV.

\section{LONG-TERM BIAS AS A PRIVATE BENEFIT?}

A well-known agency problem concerns the interest of corporate leaders in empire building-expansion of the business beyond the optimal size-when they expect

103 See Kobi Kastiel \& Yaron Nili, "Captured Boards": The Rise of "Super Directors" and the Case for a Board Suite, 2017 Wis. L. REV. 19, 27, 29-30.

$104 I d$. at 23.

105 See id. at 28-29.

106 See Lucian Arye Bebchuk \& Jesse M. Fried, Executive Compensation as an Agency Problem, 17 J. Econ. Persps. 71, 73-74, 77 (2003) (addressing the influence of management on directors); Lucian A. Bebchuk \& Assaf Hamdani, Independent Directors and Controlling Shareholders, 165 U. PA. L. REV. 1271, 1285-86 (2017) (discussing limits on the ability of independent directors to perform their oversight roles effectively); Anil Shivdasani \& David Yermack, CEO Involvement in the Selection of New Board Members: An Empirical Analysis, 54 J. Fin. 1829, 1851 (1999) (providing evidence on the involvement of CEOs in the nomination of directors).

107 See Barzuza \& Talley, supra note 6 , at 180. 
expansion would increase their private benefits. 108 This expansion comes at the expense of taking actions that may be in the interests of the company's shareholders, such as distributing dividends.109 Empire building can benefit managers in two major ways. First, the increase of resources under a manager's control is likely to provide them with pecuniary benefits, such as higher compensation 110 or an increase in their labor market value.111 Second, managers may derive nonpecuniary or psychic benefits as a result of empire building, such as appreciation, increased media coverage, or prestige. 112

A related form of psychic private benefit derives from pet projects. 113 This refers to a value-reducing business strategy that provides a corporate leader with a private benefit, either by enhancing their legacy or reputation or by moving the world in a direction that they favor. 114

108 For well-known studies that analyze empire building and management's tendency to avoid distributing cash or assets to shareholders, see, e.g., Lucian Arye Bebchuk, The Case for Increasing Shareholder Power, 118 HARV. L. REV. 833, 903-04 (2005); Sanford J. Grossman \& Oliver D. Hart, Corporate Financial Structure and Managerial Incentives, in THE ECONOMICS OF INFORMATION AND UNCERTAINTY 107, 107 (John J. McCall ed., 1982); Michael C. Jensen, Agency Costs of Free Cash Flow, Corporate Finance, and Takeovers, 76 AM. ECON. REV. 323, 323-24 (1986).

109 See Bebchuk, supra note 108, at 903-04.

110 See Jensen, supra note 108, at 323.

111 See Jeremy C. Stein, Agency, Information and Corporate Investment, in 1A HANDBOOK of THE ECONOMICS OF FinANCE 111, 122 (George M. Constantinides et al. eds., 2003).

112 See Colin F. Camerer \& Ulrike Malmendier, Behavioral Economics of Organizations, in BeHAVIORAL Economics AND Its ApPlications 235, 242-243 (Peter Diamond \& Hannu Vartiainen eds., 2007).

113 Cf. Jensen, supra note 108, at 323, 327 (describing managers' tendencies to make suboptimal investments and giving an example).

114 See Ronald J. Gilson, Controlling Shareholders and Corporate Governance: Complicating the Comparative Taxonomy, 119 HARV. L. REV. 1641, 1666-68 (2006) (observing that a controlling shareholder's decision to acquire a media or entertainment company may be motivated by the desire to increase their consumption of nonpecuniary private benefits rather than to maximize company value). 
Long-term bias resulting from overconfidence is so closely related to the agency problems of empire building and pet projects, that they are almost indistinguishable ex post and could be viewed as part of the same problem. Both long-term bias and agency problems involve corporate leaders who choose to ignore shareholder interests or market signals. ${ }^{115}$ And in both cases, corporate leaders waste free cash flow on inferior business acquisitions that provide them with some psychic private benefits. 116

The behavioral economics literature tries to distinguish between over-optimism and traditional agency theory by focusing on the intentional behavior of the decisionmakers. Unlike traditional empire builders, who consciously disregard shareholders' interests, overconfident CEOs believe they are maximizing value and acting in the interest of shareholders. 117

But from the perspective of public shareholders, should the lack of intention make such a difference? Are managers who systemically deviate from shareholder interests and who mistakenly pursue grandiose acquisitions due to overestimations of their likelihoods of success really different from those who intentionally ignore shareholder interests by engaging in empire building or pursuing pet projects? Ultimately, both types of behaviors systematically harm shareholders, and in both cases, courts are unlikely to intervene in these strategic decisions because of the deferential business judgment rule. 118

Moreover, distinguishing between overconfidence and traditional agency costs ex post could prove complicated if not impossible.119 Consider the three case studies presented by

115 For a discussion of this problem in the context of long-termism, see supra Section II.A.

116 See supra notes 108-12 and accompanying text.

117 See Barzuza \& Talley, supra note 6, at 177.

118 See Bainbridge, supra note 21, at 820.

119 Some studies have used as measures for overconfidence tallies of confidence-related mentions in the press, and the CEO's inclination to keep stock and options long after they can sell them. See, e.g., Malmendier \& Tate, Corporate Investment, supra note 10, at 2668, 2671-73 (using options- 
Barzuza and Talley: Marissa Mayer's plan to make Yahoo competitive with Google and Facebook (instead of distributing cash to shareholders); Tim Armstrong's efforts to revive AOL with his own long-term project called Patch; and Dan Ustian's plan, as CEO of Navistar, to use new and unproven technology to comply with new environmental standards. ${ }^{120}$ While they can be viewed as examples of long-term bias, an equally plausible interpretation would view them as examples of psychic private benefits.

For example, while Barzuza and Talley view AOL's investment in Patch as an example of the vulnerability of long-term projects to overconfidence, 121 it could also be viewed as the pet project of the company's then-CEO and chairman. As CNBC mentioned, "[m]any observers, including AOL shareholders, felt Armstrong clung to Patch with a kind of blind paternal love." 122

Commentators also blamed Marissa Mayer for having a pet project during her time at Yahoo. They observed that "Yahoo in February folded seven digital magazines, including titles covering food and travel, which had been a Mayer pet project. She wanted to launch dozens of vertically oriented magazines, dictating that they use Tumblr-based designs, hoping to better monetize Yahoo's monthly audience."123

related measures); Malmendier \& Tate, Market's Reaction, supra note 12 , at 40 (using a media measure). The press measure is subjective. The second measure applies only to a minority of managers who decide to keep stock and options long after they can sell them. See supra note 12 and accompanying text. Thus, distinguishing between overconfidence and traditional agency costs ex post remains a complicated task in most cases.

120 See Barzuza \& Talley, supra note 6, at 155-72.

121 See id. at 162-64.

122 Jeff Brown, Latest CEO Pet Project To Fail: AOL's Patch, CNBC (last updated Dec. 16, 2013, 3:34 PM),

https://www.cnbc.com/2013/12/16/latest-ceo-pet-project-to-fail-aolspatch.html [https://perma.cc/96JU-DM25].

123 Todd Spangler, Yahoo's False Prophet: How Marissa Mayer Failed To Turn the Company Around, YАноо (May 24, 2016),

https://www.yahoo.com/entertainment/yahoo-false-prophet-marissamayer-failed-turn-company-160630052.html] [https://perma.cc/X76CSWGB]. 
Similarly, one of the top shareholders in Navistar "would often refer to ... Ustian as a 'crazy uncle' working on a failed multibillion dollar pet project in his garage." 124

There is a third possible interpretation of these examples: that they all involve managers who in the course of fulfilling their unique visions 125 chose business strategies that failed but could have had positive expected value ex ante. Here again, in theory it is possible to distinguish between long-term bias and bad strategic decisions by focusing on the ex ante likelihood of success. Long-term bias, according to Barzuza and Talley, has negative expected value. It would always produce inferior returns - even when projects go as planned. In contrast, ordinary business failures may have positive expected value at the outset. They can produce superior returns when they go as planned but fail as a matter of chance. In retrospect, however, it could be almost impossible to distinguish between the two alternatives.

Moreover, our judgment with respect to whether a longterm bias existed ex ante suffers from a hindsight bias. Suppose that Mayer had been successful in the strategy she tried to implement. Would one still view her as suffering from long-term bias? Compare the example of Elon Musk, the founder of Tesla. Musk, "whose confidence manifests itself in unpredictable statements on Twitter about the future of ... Tesla, might be seen as the biggest example of an overconfident CEO."126 In May 2019, after Tesla's share price plunged and - with a worst-case future valuation of $\$ 10$ - the

124 Antoine Gara, Navistar Steps off the Bankruptcy Brink with Volkswagen Partnership, ForBes (Sep. 6, 2016, 10:07 AM), https://www.forbes.com/sites/antoinegara/2016/09/06/navistar-steps-offthe-bankruptcy-brink-with-volkswagen-partnership/ [https://perma.cc/3C76-MKSS].

125 See Zohar Goshen \& Assaf Hamdani, Corporate Control and Idiosyncratic Vision, 125 YALE L.J. 560, 577-79 (2016) (describing the concept of "idiosyncratic vision").

126 Josie Rhodes Cook, Bad News, Elon Musk: Overconfident CEOs at Higher Risk of Being Sued, Study Finds, InVERse (Aug. 29, 2018, 12:59 PM), https://www.inverse.com/article/48486-overconfident-ceos-are-more-likelyto-get-sued-study-says [https://perma.cc/CJP5-JMMD]. 
company neared bankruptcy, 127 one could view Musk as suffering from severe long-term bias and over-optimism. Nowadays, Tesla's share price is more than sixty times higher (reaching an all-time high price of \$695 in December 2020), 128 and Musk's strategy is a huge success story.129 Panasonic's CEO recently suggested "Elon Musk is 'a genius who defies common sense and can be overly optimistic." 130 This suggests that some CEO overconfidence could benefit shareholders. 131

The good news is that the difficulty of distinguishing ex post among the three alternative interpretations of the problems in Barzuza and Talley's case studies-agency costs, long-term bias, or mere incompetence-has limited practical significance. The cure to all of these diseases is similar: if legal rules reduce the insulation of managers from shareholder discipline, then shareholders can hold managers accountable and cause them to internalize the costs their actions

127 See Anders Bylund, Why Tesla Shares Fell 22\% in May, THE Motley Fool (June 10, 2019, 3:25 PM),

https://www.fool.com/investing/2019/06/10/why-tesla-shares-fell-22-inmay.aspx (on file with the Columbia Business Law Review) (noting that "[m]any Wall Street analysts lowered their price targets on the stock, led by Morgan Stanley dropping its worst-case valuation estimate from $\$ 97$ per share all the way down to $\$ 10$ ”).

128 Tesla, Inc. (TSLA), YAHOO! FINANCE, https://finance.yahoo.com/quote/TSLA/ [https://perma.cc/9YAH-JA83] (last accessed December 24, 2020).

129 See Panasonic CEO Says Tesla's Elon Musk a 'Genius' who Can Be 'Overly Optimistic', REUTERS (last updated July 7, 2020, 12:00 PM), https://www.reuters.com/article/us-panasonic-tesla-idUSKBN2482BF [https://perma.cc/Y5XT-A82T].

$130 \mathrm{Id}$.

131 Empirical evidence shows that overconfidence and optimism can increase firm value by counteracting risk aversion, inducing entrepreneurship, and attracting similarly-minded employees. See, e.g., Gilles Hilary et al., The Bright Side of Managerial Over-Optimism, 62 J. ACCT. \& ECON. 46, 47, 61 (2016) (arguing that over-optimism may increase managerial investment and effort); Simon Gervais \& Itay Goldstein, The Positive Effects of Biased Self-Perceptions in Firms, 11 REV. FIn. 453, 45557 (2007) (suggesting that overconfident individuals may be more likely to engage in entrepreneurship and work well in teams). 
generate.132 Managers who underperform and ignore indications of shareholder dissatisfaction would face the possibility of removal, regardless of whether the cause of such failure is long-term bias, incompetence, or the excessive consumption of private benefits of control. Conversely, overoptimistic managers who perform well (like Musk) are likely to receive shareholder support and remain in office.

Finally, it is worth noting that, according to Barzuza and Talley, the distinction between the long-termism interpretation they posit and agency cost theory does play an important role in at least one context: executive compensation. In particular, they argue that incentive-based compensation could mitigate agency costs but does not ameliorate-and even could aggravate-long-termism. This is because overconfident managers probably invest even more in long-term projects when their compensation is tied to firm value. 133 In practice, however, it would be extremely difficult to determine in advance which managers suffer from longterm biases and adjust their compensation accordingly. Since many managers do respond to financial incentives and market signals, 134 it could be counter-productive not to tie their compensation to their firm's long-term value.

\section{IMPLICATIONS}

Most of Barzuza and Talley's policy recommendations are similar to the recommendations for mitigating managerial agency costs. They call for reducing the insulation of managers from market forces and shareholder disciplinary power.135 They also oppose limitations on dividend distributions that could exacerbate management free cashflow problems, suggest increasing managerial accountability, and support enabling hedge funds to engage with targets. 136

132 For a fuller discussion of the arguments about discipline summarized in this paragraph, see supra Sections II.A \& II.B.4.

133 See supra notes 47-48 and accompanying text.

134 For a discussion of incentives, see supra Section II.A.

135 See Barzuza \& Talley, supra note 6, at 170-81.

136 See id. at $179-83$. 
As a result, they oppose the reforms proposed by the Brokaw Act as well as additional reforms to curb quarterly reporting. 137

These recommendations are reasonable and convincing. As long as the legal system provides shareholders with adequate tools for disciplining underperforming CEOs and incentivizing them to take shareholder interests into account, the underlying reason for the underperformance of managers-whether it is long-term bias, managerial slack, or self-interest-should not matter. 138 In that sense, one of Barzuza and Talley's most important contributions is to provide an additional justification for reducing managerial insulation.

My support of the authors' normative conclusions has one major exception: their acceptance of the use of dual-class stock. They argue:

[W]e are reluctant to advocate for a blanket prohibition on dual class stock (as others have championed). It is difficult indeed for outsiders to unpack the motivations of a founder who embraces a dual class structure; it may be due to overconfidence (and thus value-eroding), but it could just as easily be due to a founder's genuine desire to protect a project that is inherently difficult for outsiders to assess. Moreover, the founder might simply place idiosyncratic value on maintaining control, and is willing to incur the costs of doing so in the form of the price discount that outside investors will no doubt impose on the sale (particularly if they are short-term oriented). Whatever their motivation, dual-class founders will internalize the loss. 139

137 See id. at 117-18 ("The Brokaw Act, for example, which would constrain hedge fund activists through a variety of disclosure and liability measures, was reintroduced on August 31, 2017. . . Our analysis counsels some degree of caution in pursuing these legal and regulatory interventions that are predicated largely on insulating corporate decision making from the forces [of] short-termism.").

138 See supra Part III.

139 Barzuza \& Talley, supra note 6, at 184-85 (footnote omitted). 
If corporate leaders can internalize the costs of choosing dual-class shares at the IPO stage, then why can't they internalize all other costs caused later on by their inferior long-term investment decisions? Barzuza and Talley's analysis depends on the assumption that corporate leaders are unable to internalize the costs of their long-term investment decisions; otherwise, they would avoid such loselose investments (which would lead both to delayed realization of investments and inferior returns). There is no reason to believe that corporate leaders would behave differently at the IPO stage. 140

Most importantly, the use of dual-class stock is likely to aggravate the problem of long-term bias because it fully insulates corporate founders from market forces and activist hedge funds. Such funds, according to Barzuza and Talley, "may represent an efficient counter-ballast against"141 managerial long-termism. ${ }^{142}$ Consequently, those who support legal rules that reduce managerial insulation and enable the activity of activist hedge funds because they believe that such rules are value-increasing should also oppose the use of perpetual dual-class stock.

140 For the view that the choice of IPO governance arrangements could be imperfect, see Lucian Arye Bebchuk, Why Firms Adopt Antitakeover Arrangements, 152 U. PA. L. REV. 713, 719, 740-42 (2003) (discussing the pricing of governance terms and managers' perverse incentives at the IPO stage); Michael Klausner, Fact and Fiction in Corporate Law and Governance, 65 STAN. L. REV. 1325, 1370 (2013) ("Doubts have been raised regarding whether pre-IPO shareholders bear a cost when they take companies public with staggered boards.”). Of course, some might oppose, as a matter of principle, any mandatory limitation on the terms that founders may offer when going public. But that view generally assumes a high degree of market efficiency that should also obtain midstream. For those who are open to restricting or discouraging value-reducing IPO governance terms, I explain in this Section why perpetual dual-class structures are unlikely to be value enhancing.

141 Barzuza \& Talley, supra note 6, at 117.

142 See Lucian A. Bebchuk \& Kobi Kastiel, The Untenable Case for Perpetual Dual-Class Stock, 103 VA. L. REV. 585, 602-03 (2017) (discussing managerial incentives). 
While corporate founders could have a unique vision, 143 they also could suffer from overconfidence and be less likely to listen to others. 144 With a perpetual lock on control and limited equity stake-both due to their company's dual-class structure - such founders would have full insulation from the market for corporate control. They could remain in office even if they pursued inferior long-term projects over and over. There would be no institutional brake on any form of longtermist overinvestment by these founders, and distortions of their incentives would be significantly more severe than comparable distortions in the context of widely-held companies. 145

In a recent article co-authored with Lucian Bebchuk, we analyze the major costs and risks arising from an extremely long lock on control.146 Changes in the controlled company and its business environment might well change the type of leader that would be most appropriate for that company. ${ }^{147}$ For example, technology companies often operate in a dynamic business environment with disruptive innovations and significant changes over time. 148 In such an environment, even highly talented and successful founders can lose their "golden touch," but not necessarily their overconfidence and optimism, after many years of leading their companies. ${ }^{149}$ In the same article, we also show that controllers have strong incentives to retain a dual-class structure even when that structure becomes inefficient over time.150 Therefore, even those who support the use of dual-class stock should recognize the existence of a major risk, likely increasing over time, that

143 See Goshen \& Hamdani, supra note 125 , at 568.

144 See Barzuza \& Talley, supra note 6, at 138-39 (discussing overconfidence among entrepreneurs); Camerer \& Lovallo, supra note 24, at 306-07.

145 See supra Section II.B.4.

146 See Bebchuk \& Kastiel, supra note 142, at 602-09.

147 See id. at 604-06.

148 See id. at 589.

149 See id. at $604 \&$ n.62, 605-06 (discussing this problem, including in the technology context).

150 See id. at 612-17. 
company founders will remain in power even after they become value-reducing leaders.

Furthermore, as the founder's equity stake declines due to the use of dual-class stock, the expected governance costs go up at an increasing rate, and the problem of long-term bias becomes more serious. The founder could make inferior longterm acquisitions that would increase substantially the size of the company while reducing the wealth of the company's preacquisition shareholders. In such a scenario, the costs of the acquisition would be divided among shareholders pro rata, but, by increasing the company's size and importance, the acquisitions could increase the founder's influence, power, and stature, thereby providing them with a significant private benefit.151 As a result, there may be a wide range of acquisitions or investments that the controlling founder would have private incentives to pursue even though such value-reducing, long-term acquisitions would make all other shareholders substantially worse off. 152

Indeed, I believe that Barzuza and Talley's analysis provides a strong justification for not insulating smallminority controllers perpetually from shareholder intervention through the use of dual-class stock.

\section{GOING FORWARD}

In a thought-provoking and important piece, Barzuza and Talley make an important contribution to the research exploring the interaction of corporate law and behavioral psychology. They show how corporate managers often fall prey to excessive optimism about their own long-term projects, and they illustrate this long-term bias using case studies from three prominent companies. It is certainly required reading in this field, providing an additional important justification for policymakers and legal scholars not to embrace reforms that

151 For a fuller discussion of this problem, see Lucian A. Bebchuk \& Kobi Kastiel, The Perils of Small-Minority Controllers, 107 GEO. L.J. 1453, 1465-71 (2019) (discussing such controller strategies).

152 Id. at 1469-71 (discussing such controller strategies). 
increase managerial insulation and focus mostly on shortterm bias.

This Comment argues that the presence of proper incentives likely will elicit less biased and more accurate judgments. In particular, the potentially adverse effects of long-term biases on executive compensation, company share price, and CEO tenure provide most managers with incentives to be less optimistic and to avoid inferior long-term investments in the first place.

I also question whether Barzuza and Talley's theory is empirically testable given the difficulties in distinguishing among long-term bias, traditional agency theories of empire building and pet projects, and mere incompetence. This helps explain why the cure for both long-term bias and agency costs is similar: reducing the relative insulation of the board from shareholders' disciplinary power.

Finally, I express strong support for most of the normative conclusions of the authors, with one important exception: their acceptance of the use of dual-class stock. With a perpetual lock on control and a tiny equity stake, corporate leaders could remain in office even if they pursued inferior long-term projects over and over.

All of this suggests that the theory presented by Barzuza and Talley opens some interesting avenues for future research. The first avenue relates to the magnitude of the problem of long-term bias. How prevalent is long-term bias among CEOs? To what extent could various financial incentives mitigate it?

A second avenue of research would explore which types of managers are most likely to be subject to long-term bias. For this purpose, it would be interesting to compare founders with professional CEOs and to explore other factors that could affect a CEO's time biases, such as the length of the CEO's tenure and the equity stake of the CEO. It also would be interesting to examine whether long-term bias is more severe in the case of companies near the ends of their life-cycles. One would assume that managers of these companies-such as the CEOs of Yahoo or AOL-would be unwilling to admit that they failed to turn the company around and then suffer the 
reputational effects associated with that business failure. Thus, they may be likely to keep making inferior investments rather than dissolve the company. Exploring the factors that would help investors and boards determine ex ante which CEOs are more likely to be prone to long-term bias would also enable them to adopt governance measures that could mitigate this bias.

Barzuza and Talley's article is an additional, important step toward a richer discussion of the influence of behavioral biases, such as overconfidence and optimism, on managerial decisionmakers. Hopefully, future legal and empirical studies will shed more light on this important and interesting topic. 